\title{
Biological control of sweet chestnut on Pécsbánya, Hungary
}

\author{
Gabriella Kovács - Dominika Bodnár - Gábor Tarcali - László Radócz \\ University of Debrecen, Faculty of Agricultural and Food Science and Environmental Management, \\ Department of Plant Protection, Debrecen \\ kovacs.gabriella@agr.unideb.hu
}

\begin{abstract}
SUMMARY
The supervision of plant hygiene of sweet chestnut grove on Pécsbánya (South Hungary) started more than four years ago. Hypovirulent strains were applied as a biological process to control Cryphonectria parasitica fungus which causes the chestnut blight disease. By now the performed interventions have shown obvious results, the vitality of the trees has greatly improved, the amount of harvested nuts is increasing, and the hypovirulent strain has been spreading within the area. During plant health inspection the galls of chestnut gall wasp (Dryocosmus kuriphilus) was found in the year of 2015, which is the obvious symptom of new occurrence of the pest. The pest was eradicated by destroy galls, which allows taking out of consideration the damage by now in this area.
\end{abstract}

Keywords: Cryphonectria parasitica, Dryocosmus kuriphilus, chestnut blight, biocontrol

\section{INTRODUCTION}

The sweet chestnut belongs to the family of Fagaceae, in the genus of Castanea, in which has several known species. In Europe the sweet chestnut (Castanea sativa) is native, in eastern North America the American chestnut (Castanea dentata) was the only native species, it could grow up to 30-40 meters. Chinese chestnut (Castanea mollissima) can be found in China and Japanese chestnut (Castanea crenata) is native in Korea and Japan.

As C. sativa likes the Mediterranean climate, therefore its natural occurrence is geographically relatively narrow. It is endemic in the Carpathian Basin too (Csapody 1972). Its presence is located in the Zala and Somogy hilly counties, but it also can be found in the Mecsek Mountains (Southern Hungary) and in the Danube bend area (Northern Hungary). These areas situated on the northern edge of the natural zone of European chestnut.

Chestnuts have many known fungal pathogens, however one of the most significant diseases in the last century were Phytophthora dieback disease (Phytophthora sp.) and Chryphonectria parasitica (Murill) M.E. Barr [syn.: Endothia parasitica (Murr.) Anderson] (anamorph: Endothiella sp.) fungus the causing agent of chestnut blight of European and American chestnut trees. Nowadays, the appearance of chestnut gall wasp (Dryocosmus kuriphilus) poses significant risk. The chestnut gall wasp is mostly spread with propagating material from west and south countries of Europe. The insect laying eggs into the buds of the young shoots during the summer and the adults fly out of the galls next spring. Due to the formation of galls on the leaves the green parts of chestnut trees are destroyed, the leaf surface and vitality of the trees decrease so become dangerously debilitated in a few years. The control to this pest is difficult as adults are found outside of the gall only for a short time. So there is a very limited time for effective chemical control, moreover there are no licensed insecticides in Hungary against them.
According to the American, Japanese and Italian research results, most of tested insecticides are ineffective for gall wasps (Net1). The solution can be the application of biological control. The natural enemy of the gall wasps is a parasitoid wasp (Torymus sinensis), but this species is not native in Europe. Some papers referred about in vitro propagation of the parasitoid wasps and placing them directly on the infested trees (Melika et al. 2003, Kriston et al. 2015).

Phytopthora dieback disease can be caused by several Phytopthora species, mainly by Phytophthora cambivora and Phytophthora cinnamomi fungi. In Hungary, these symptoms were observed in the area of Pécsvárad and Zengővárkony in the late 1970's (Eke and Gál 1977). The most typical symptom is discoloration of the root collar zone on sweet chestnut. Other symptoms are smaller size leaves, dropping off the catkins and drying of the shells on the branches. The roots are also seriously damaged which results none or very limited formation of root sprouts. The Asian chestnut species are tolerant to the dieback disease so in the 1920's these were used in the nurseries as rootstocks in Europe.

The Cryphonectria parasitica (Murr.) Barr fungus appeared in the early 1900's on the eastern coast of the United States (Merkel 1906), and during almost 40 years has nearly destroyed the whole sweet chestnut population on 4 million hectares of forest surface area. After its appearance in Europe, blight disease has also spread rapidly because of the multi-step introduction. Cryphonectria parasitica fungus is a wound parasite, the symptoms of the infection are perceptible especially on young trees. Reddish brown flags appear on the branches and later on, after relatively rapid invasion of the mycelium the bark is cracking and orange stromata appear on it. Older trees, which have been previously impact the bark on, the appearance of fungus are less noticeable in the early stages, later the foliage of tree is drying in an abnormal period, but it does not fall down. The fungus penetrates into the bark and cambium tissues, destroys them, thus preventing the normal operation of water transport 
system. Due to the lack of water over the cankers the branch dies and the bark torn. Once the fungus has colonised the bark and cambium tissues, it is also penetrates the outer xylem cells of the tree (Eke and Gál 1975).

In 1960, near to Verona city, Italy, a heavily infected plantation by the blight fungus was discovered (Biraghi 1968), but did not show the signs of death, and the necroses were recovered. It was concluded that the increased resistance of the trees or a decrease in the virulence of the pathogen had caused the phenomenon. The second assumption was justified by Grente (1965) after artificial inoculation studies. The hypovirulence is a phenomenon which is responsible for the change in the physiological functions of the pathogenic fungus. This reduced pathogenicity or hypovirulence of wild strains caused by virus-like particle (VLPs), located in the cytoplasm of the pathogenic fungus. This double-stranded RNA encoded VLPs, known mycoviruses now (fam. Hypoviridae, gen. Hypovirus, type species Cryphonectria hypovirus 1, CHV-1,CHV-2,CHV-3, and $C H V 4$ ) (ICTV, 2014 release) can be transmitted from infected fungus to a virulent fungus strain via hyphae-anastomoses if vegetative compatibility exists among them viz. they belong to the same vegetative compatibility group.

In many areas of the Mecsek hills, we can encounter large extensions of sweet chestnut. There was not available valid records for their age, but it may be assumed that those trees could be more than hundreds years old. Because of the blight disease, a large part of the chestnut population has already been destroyed. The sweet chestnut produce root sprouts well, so the park of about 2 hectares consist of chestnut root sprouts mainly close to Pécsbánya (South Hungary)

\section{MATERIALS AND METHODS}

At the beginning of the 2000's László Radócz biocontrol treatments by Cryphonectria parasitica hypovirulent strains in the chestnut park close to Pécsbánya and in other parts of the Mecsek mountains. The Pécsbánya site was revisited and checked in 2014. Due to the previous treatments, besides the virulent strains of the fungus, the hypovirulent strains were also found in the area. Samples were collected from both types of bark necroses to the laboratory examinations.

Sampling process: cutting off a piece of bark from the border of healthy and infected bark tissue. After each sampling, the cutting tool was disinfected in $70 \%$ ethanol. The collected samples were placed individually in paper bags and stored in a refrigerator until laboratory isolation.

The first step in the laboratory isolation is the samples slicing up to small pieces and disinfected in $70 \%$ ethanol for 2 minutes and then washed in a sterile-distilled water for another 2 minutes. Subsequently, the samples were placed on Potato Dextrose Agar (PDA) and stored in a thermostat (constant at $22-23{ }^{\circ} \mathrm{C}$ ). The Plant Protection Institute of University of Debrecen, Hungary has a large collection of many virulent and hypovirulent $C$. parasitica strains and isolates. During the laboratory conversion, virulent and hypovirulent samples from Pécsbánya were used. Small pieces (cca. $5 \times 5 \times 2 \mathrm{~mm}$ ) of media covered by the fungus were cut out from the virulent and hypovirulent colonies and were put tightly to each other on the surface of PDA medium. The mycovirus carried by the hypovirulent strain transferred via the hypae-anastomosis to the virulent one if the vegetative compatibility exists among them (positive vegetative compatibility). In other cases the fusioned mycelia quickly died right after of hyphae anastomosis resulting a barrage line. Growing of incompatible fungal strains continued growing on independently from each other. However, if the fungal mycelia were mated (positive), then barrage line did not develop on the medium.

After laboratory identification of compatibility between hypovirulent and virulent strains the compatible hypovirulent one were propagated and Petri dishes were sealed.

The course of in situ biological control treatment was as follows: the canker on the trunk or branch of sweet chestnut had been drilled surrounding in brownish coloured tissues by using hand drills, making holes about $10 \mathrm{~mm}$ in diameter, keeping 2-5 $\mathrm{cm}$ distance between inoculation holes. Hypovirulent strain-coated medium discs were placed into the holes and the wound were sealed by sticking plaster. This is necessary to fix discs, preventing their shortly drying out and/or even consuming them by any insect. The hypovirulent strain grows into the bark during a few days and very likely contacts the virulent strain of pathogen. Then similar conversion processes occur by in situ anastomoses as it was observed in the laboratory (Figure 1).

Figure 1: In situ biological control treatments to Cryphonectria parasitica by a hypovirulent strain in Pécsbánya (Southern Hungary)
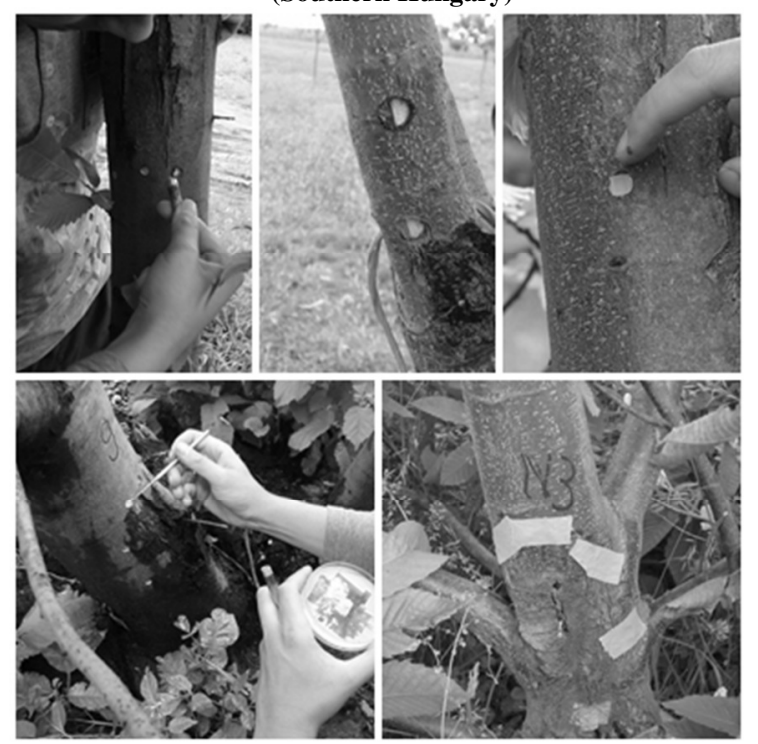
Trees in the sweet chestnut park of Pécsbánya have been treated for four years. Every year the area was surveyed in spring and in autumn. Treatments contribute to the obvious results, harvesting more chestnut year by year, and the improving chestnut park also serve as a place for cultural events.

The former maintainer of the site was responsible to the slightly uncared area from April 2014 until the end of June 2015 and released increasing parts from repressive undergrowth.

During the last four years samples of infected and the healing parts of the chestnut barks were collected including hypovirulent strains from 4 geographically different Hungarian sites. Hypovirulent strain occurence is the most common in Nagymaros region (Danube bend area, Northern Hungary). However, there was an unusual case that a single injury did not start healing, despite of multiple treatments. According to our assumptions, a strain belongs to a new vegetative compatibility group appeared in the area. Taking samples of these canker, cultured and tested with 3 other hypovirulent strains of the collection.

Under laboratory conditions a hypovirulent strain isolated from Rezi (North to Balaton Lake), proved to be appropriate. By using this hypovirulent strain the in situ treatment was performed in late autumn of 2017 and its efficacy will be checked in the spring of 2018. During 2014 and 2017 years the chestnut park near Pécsbánya were examined 6 times. During biological treatments the GPS coordinates of each tree were recorded and are shown on the picture originated from Google Earth (Figure 2).
Figure 2: Upper part - marked treated trees in Pécsbánya

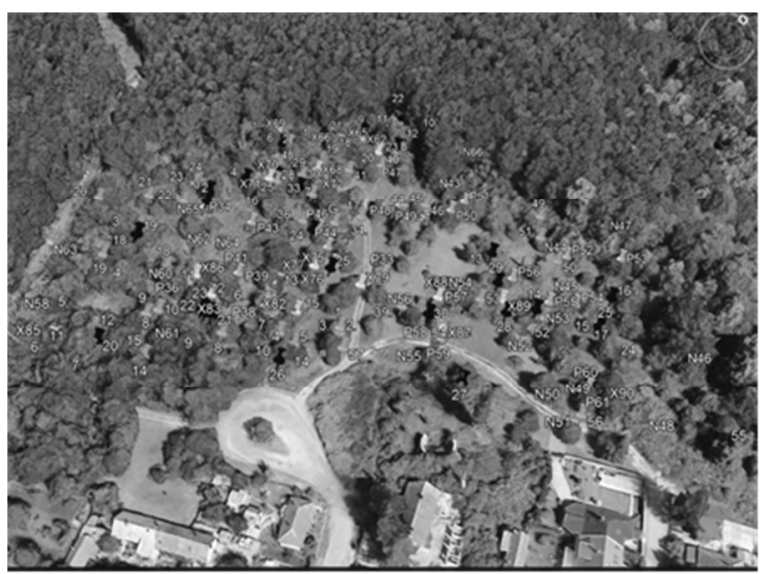

In addition to recording the exact locations, photos were also taken to prove damages and post-treatment status. All treatments were marked by appropriate code system consist of different letters and numbers (P1, N2, X3 etc.). As more than 400 treatments were performed, so almost 900 photos were taken to document the curing efficacy in every six month before and after treatments.

It is very clear how the barks were callusing year after year and the tree becomes completely healed. All in all, just over $6 \%$ of all treatments had to be retreated (Table 1).

The number of biocontrol treatments by hypovirulent strains of Cryphonectria parasitica on infected chestnut trees in 3 parts of Pécsbánya park between 2014 and 2017

\begin{tabular}{lcccc}
\hline \multicolumn{1}{c}{ Date of treatment } & Lower part & Mid part & Upper part & Repeated treatments \\
\hline 20. 05. 2014 & 19 & 0 & 0 & 0 \\
29. 09.2014 & 11 & 24 & 30 & 1 \\
23. 05. 2015 & 20 & 9 & 57 & 5 \\
05. 11.2015 & 29 & 3 & 28 & 0 \\
18. 05. 2016 & 30 & 10 & 24 & 1 \\
08. 10.2016 & 0 & 0 & 25 & 6 \\
19. 05.2017 & 61 & 0 & 28 & 12 \\
All & 170 & 46 & 192 & 25 \\
\hline
\end{tabular}

\section{RESULTS}

New disease occurrences were observed on a yearly basis, e.g. 89 new occurrences were detected in the spring of 2017. Recovering process has also been followed and within one-two years the treated lesions were qualified as perfectly recovered, assigned +++ (Table 2). For confirmation purposes, the samples were collected from previously treated barks to reisolation. The reisolated fungus did not shown the characteristic orange colour pigmentation on PDA which is the own of virulent strain only.

Pécsbánya park consist of 450 chestnut trees staying solitary or in small groups. The treated trees were $18 \%$ in 2014 and $30 \%$ in 2015 respectively. Area of the park was extended in 2015 and during cleaning works viz. removing repressive undergrowth a lot of new wound was made which contributed to the new infections of wound-parasite Cryphonectria parasitica fungus. The rate of treatments decreased again by $18 \%$ in the year of 2016.

The progression of recovery of bark cankers on infected trees was evaluated two times a year with an exception of autumn of 2016 due to a cultural event viz. 'Gesztenyeliget festival'. The first perfectly recovered bark cankers were noticed cca. one year after the treatments. The progression of recovery was increasing is percentage of treatments as high as one third of previously infected trees (35\%) (Figure 3). 
The curing process - Number of treatments and curing stages during 2014 and 2017 on Pécsbánya

\begin{tabular}{|c|c|c|c|c|c|}
\hline \multirow[b]{2}{*}{ Date of treatments } & \multirow[b]{2}{*}{$\begin{array}{l}\text { Number of } \\
\text { treatments }\end{array}$} & \multirow{2}{*}{$\begin{array}{c}\text { Repeated } \\
\text { treatments } \\
(-)\end{array}$} & \multicolumn{3}{|c|}{ Curing process of cancer } \\
\hline & & & $\begin{array}{c}\text { Initial } \\
(+)\end{array}$ & $\begin{array}{c}\text { Advanced } \\
(++)\end{array}$ & $\begin{array}{l}\text { Perfectly recovered } \\
\qquad(+++)\end{array}$ \\
\hline 2014 Spring & 19 & 0 & 0 & 0 & 0 \\
\hline 2014 Autumn & 65 & 1 & 15 & 4 & 0 \\
\hline 2015 Spring & 86 & 5 & 44 & 37 & 4 \\
\hline 2015 Autumn & 60 & 0 & 62 & 76 & 34 \\
\hline 2016 Spring & 64 & 1 & 59 & 110 & 74 \\
\hline 2017 Spring & 89 & 12 & 63 & 60 & 103 \\
\hline
\end{tabular}

Figure 3: The progress in curing sweet chestnut cankers after treatments by hypovirulent strains

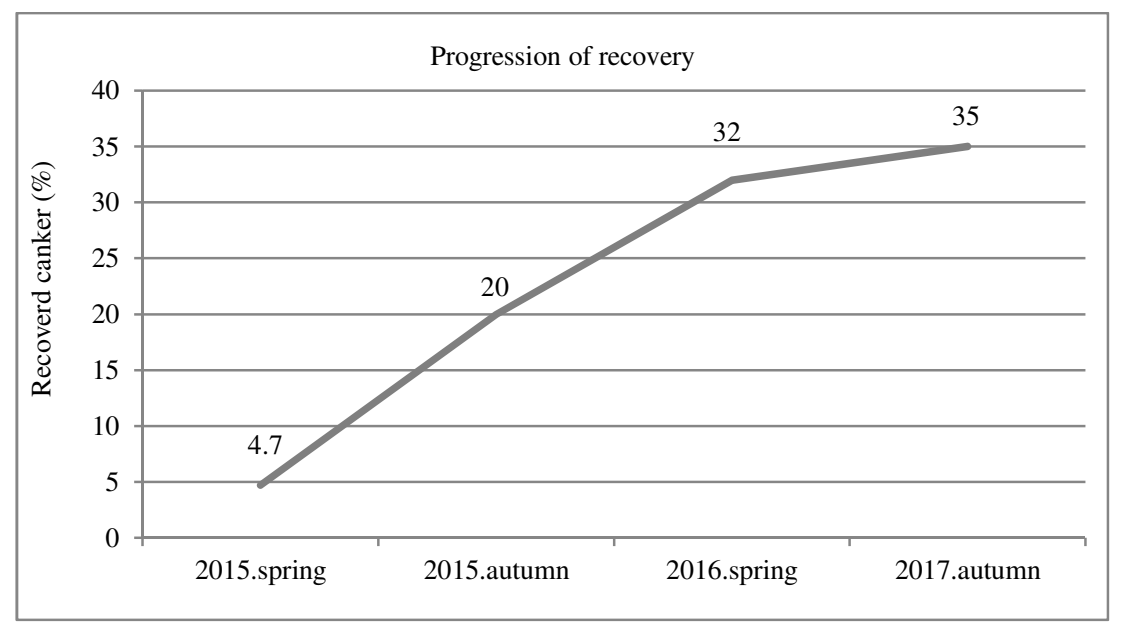

Many cases the spreading of hypovirulence was also observed near to those trees which had been treated before by callus forming and decreasing of bark necroses symptoms on the surrounding trees.

In May of 2016 a tree was observed near to the upper part of the chestnut park with some galls of chestnut gall wasp (Dryocosmus kuriphilus). As the gall wasp has no natural enemies in our country, so we took off the galls and destroyed them to prevent further reproduction. Probably there could remain some more galls in the higher parts of the tree, as we observed new galls on the next spring (Figure 4).

\section{CONCLUSIONS}

European sweet chestnut is highly susceptible to the infection of chestnut blight fungus, Cryphonectria parasitica. In the fall of 2016, due to the Gesztenyeliget festival there was not available to make treatments on Pécsbánya lower area, and in the next half of the year twice as much damage was occurred to be treated than as usual expected. It follows that the treatment of areas infected with chestnut blight fungus can be only effective if mechanical protection and cleaning interventions are performed regularly and professionally by making as few wound as possible.
Figure 4: Occurrence of galls of chestnut gall wasp (Dryocosmus kuriphilus) in Pécsbánya

(above - galls on the leaves, below - the location of the two trees on which galls were found)

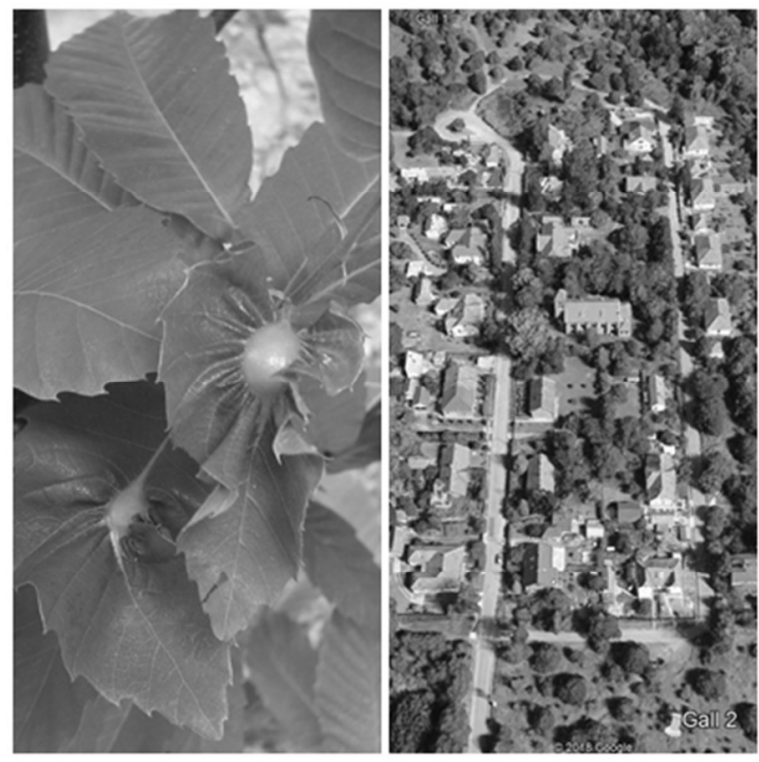


In Pécsbánya park, belongs to the Mecsek mountains area, during the 4 years (2014-2017) inspection and biological control there was only isolated one strain of chestnut blight fungus. However, recently was discovered a chestnut blight canker, which caused by a fungal strain belonging to a new vegetative compatibility group. Therefore it is important to collect samples from infected barks every time so that monitoring allows to observe the appearance of any new VCGs (vegetative compatible groups).

Amongst our further goals are to analyze effectiveness of biocontrol process by noting number of infected tree groups/root sprouts -and number and proper time of treatments. This way it should be available to follow the efficacy of biocontrol treatments and natural spreading of hypovirulent strains among chestnut tree population. These surveys are planned to be made at parallel with treatments at the autumn of 2018.

\section{ACKNOWLEDGEMENT}

The publication is supported by the EFOP 3.6.1-162016-00022 project. The project is co-financed by the European Union and the European Social Fund.

\section{REFERENCES}

Biraghi, A. (1968): La rinascita del Castagno dagli orrori del cancro. L'Italia Agricola. 105: 485-490.

Csapody I. (1972): Öshonos-e a szelídgesztenye (Castanea sativa Mill.) hazánkban és Közép-, ill. Dél-Európában? Erdészeti és Faipari Tájékoztató. Sopron. 49-61.

Eke I.-Gál T. (1975): Az Endothia parasitica (Murr.) Anderson elterjedése Magyarországon és a védekezés lehetőségei. Növényvédelem. 11: 405-407.

Eke I.-Gál T. (1977): Az Endothia parasitica (Murr.) Anderson aszkospóra szóródásának éves menete. Növényvédelem. 13: $352-358$

Grente, J. (1965): Les formes hypovirulentes d'Endothia parasitica et les espoir de lutte contre le chancre du châtaignier. Acad. Agric. France. 51: 1033-1036.

ICTV (2014): Virus Taxonomy. EC 46, Kingston and Montreal. Canada. July 2014. https://talk.ictvonline.org/taxonomy/
Kriston É.-Bozsó M.-Krizbai L.-Csóka Gy.-Melika G. (2015): Klasszikus biológiai védekezés Magyarországon a szelídgesztenye gubacsdarázs Dryocosmus kuriphilus (Yasumatsu, 1951) ellen: előzetes eredmények. Növényvédelem. 51. 10: 445-450.

Melika G.-Brussino, G.-Gianfranco, B.-Csóka Gy. (2003): Szelídgesztenye-gubacsdarázs (Dryocosmus kuriphilus Yasumatsu 1951 - Hymenoptera: Cynipidae), a szelídgesztenye új kártevője Európában. Növényvédelem. 39. 2: 59-63.

Merkel, H. W. (1906): A deadly fungus in the American chestnut. NY. Zool. Soc. Am. Rep.

Net1: http://portal.nebih.gov.hu/informaciok/noveny/hivatali/erdo/ erdo-hivatali/-/asset_publisher/4ndba0yRXvQX/content/ szelidgesztenyeink-ujabb-nem-honos-kartevoje-aszelidgesztenye-gubacsdara-1/fajleiras-boom-a-mikroszkopalol-nebih-elelmiszer-tudomany-ripka-geza-atka-gubacsatka 